University of Montana

ScholarWorks at University of Montana

$5-2002$

\title{
The Fitness Consequences of Interspecific Eavesdropping Between Plants
}

Richard Karban

University of California - Davis, rkarban@ucdavis.edu

John L. Maron

University of Montana - Missoula, john.maron@mso.umt.edu

Follow this and additional works at: https://scholarworks.umt.edu/biosci_pubs

Part of the Biology Commons

Let us know how access to this document benefits you.

\section{Recommended Citation}

Karban, Richard and Maron, John L., "The Fitness Consequences of Interspecific Eavesdropping Between Plants" (2002). Biological Sciences Faculty Publications. 345.

https://scholarworks.umt.edu/biosci_pubs/345

This Article is brought to you for free and open access by the Biological Sciences at ScholarWorks at University of Montana. It has been accepted for inclusion in Biological Sciences Faculty Publications by an authorized administrator of ScholarWorks at University of Montana. For more information, please contact

scholarworks@mso.umt.edu. 


\title{
THE FITNESS CONSEQUENCES OF INTERSPECIFIC EAVESDROPPING BETWEEN PLANTS
}

\author{
RICHARD KARBAN ${ }^{1,3}$ AND JOHN MARON ${ }^{2}$ \\ ${ }^{1}$ Department of Entomology, University of California, Davis, California 95616 USA \\ ${ }^{2}$ Department of Botany, University of Washington, Box 355325, Seattle, Washington 98195-5325 USA
}

\begin{abstract}
Although many ecologists have discounted the possibility of communication between plants, recent work demonstrates that wild tobacco plants with experimentally clipped sagebrush neighbors suffer less leaf herbivory than tobacco controls with unclipped neighbors. In this report, we examine the fitness consequences of resistance induced by eavesdropping. Annual tobacco plants with clipped sagebrush neighbors produced more flowers and seed-bearing capsules than plants with unclipped neighbors although these performance measures varied considerably over the five years of the study. Tobacco plants with clipped neighbors also suffered more frost damage than controls in one year. There was no indication that eavesdropping was more beneficial to tobacco in years with high risk of herbivore damage. The potential adaptive benefits of eavesdropping remain unclear based on five years of data. However, the fact that eavesdropping had strong effects on herbivory and plant performance suggests that interactions between plant species may be richer than we previously suspected.
\end{abstract}

Key words: Artemisia tridentata; communication between plants; eavesdropping; fitness; induced defense; Nicotiana attenuata; talking trees.

\section{INTRODUCTION}

The possibility of communication between plants in response to herbivory has been an intriguing subject that has sparked considerable controversy over the past 20 years (see reviews by Fowler and Lawton 1985, Bruin et al. 1995, Shonle and Bergelson 1995, Karban and Baldwin 1997:39-46). Early reports of this phenomenon (Baldwin and Schultz 1983, Rhoades 1983, Bruin et al. 1992) suffered from limited replication and failure to consider alternative hypotheses, prompting most ecologists to dismiss the possibility completely. In addition, critics have questioned why damaged plants should dispense information that other, unrelated, individuals can use. However, the notion that plants respond to cues that have been released involuntarily by damaged neighbors is consistent with natural selection acting at the individual level. Exploitation of cues released by herbivores or neighboring plants damaged by herbivores can be considered a special form of communication that animal behaviorists term “eavesdropping" (Bradbury and Vehrencamp 1998). As we use the term, eavesdropping refers to the exploitation by a receiver of cues released voluntarily or involuntarily by an emitter and implies no fitness benefits for either.

Recent experiments indicate that eavesdropping between plants may occur. In the Great Basin, annual wild tobacco often grows in close proximity to sagebrush

Manuscript recieved 19 March 2001; revised 27 August 2001; accepted 7 September 2001; final version received 16 October 2001.

${ }^{3}$ E-mail: rkarban@ucdavis.edu
(Wells 1959; R. Karban and J. Maron, personal observation). Wild tobacco plants (Nicotiana attenuata) induced resistance when neighboring sagebrush (Artemisia tridentata) were experimentally clipped with scissors (Karban et al. 2000). In each of three years (1996-1998), damage caused by grasshoppers, the primary folivores, was reduced on tobacco plants with experimentally clipped sagebrush neighbors. Activity of polyphenol oxidase (PPO), an antinutritive oxidative enzyme, was elevated in tobacco plants near clipped sagebrush neighbors compared to tobacco near unclipped sagebrush (Karban et al. 2000).

Previous work has revealed hints about the mechanism of eavesdropping between tobacco and sagebrush. When soil contact between sagebrush and tobacco was blocked, tobacco was still more resistant near clipped sagebrush. When air contact was blocked, no induced resistance was observed (Karban et al. 2000). These results indicate that an airborne cue is probably involved in some form of eavesdropping under field conditions. These results were not caused by grasshoppers avoiding damaged sagebrush (Karban and Baxter 2001) or by changes in the microenvironment caused by clipping (Karban et al. 2000).

While induced resistance caused by cues released by clipped sagebrush makes neighboring tobacco plants less likely to get damaged by herbivores, it is unclear whether this translates into differences in plant performance. Since our experimental clipping provided tobacco plants with cues indicating high risk of herbivory, we expected that eavesdropping might benefit tobacco plants during years when actual risk of herbivory was high (Karban et al. 1999). However, in years 
when risk of herbivory was low, the information provided by experimentally clipping neighboring sagebrush might cause tobacco to increase defenses when elevated defenses actually were not appropriate. Under such conditions, eavesdropping on neighboring clipped sagebrush might be costly to tobacco plants.

Building on past work, here we ask whether proximity to experimentally clipped sagebrush and concomitant reductions in levels of natural herbivory result in increased plant fitness. If so, does induced resistance benefit tobacco in years when risk of herbivory is high but reduce tobacco fitness in years when risk of herbivory is low?

\section{Methods}

Sagebrush is the dominant plant of the Great Basin; tobacco often has sagebrush as its neighbor although tobacco is only an infrequent neighbor of sagebrush. Wild tobacco suffers high rates of leaf herbivory by grasshoppers (six species, in order of abundance: Cratypedes neglectus, Trimerotropis fontana, Conozoa sulcifrons, Cratypedes lateritius, Melanoplus sanguinipes, and Cordillacris occipitalis) and noctuid cutworms (two common species: Peridroma saucia and Agrotis ypsilon). These generalist herbivores also feed on $A$. tridentata although sagebrush tends to be preferred earlier in the season when tobacco and other annual plants are seeds or small seedlings.

All of our experiments were conducted on the floodplain of Convict Creek at the Sierra Nevada Aquatic Research Laboratory (SNARL) near Mammoth Lakes, California, USA $\left(37^{\circ} 36^{\prime} 57^{\prime \prime} \mathrm{N}, 118^{\circ} 49^{\prime} 47^{\prime \prime} \mathrm{W}\right)$ at an elevation of $2160 \mathrm{~m}$. Although wild tobacco grows at this site, it was not naturally abundant enough to fulfill the desired levels of replication, so tobacco plants were transplanted as small seedlings from local sites. Tobacco seedlings were transplanted within $15 \mathrm{~cm}$ downwind of an established sagebrush plant. Treatments were applied only after tobacco plants had completely recovered from transplanting $(9-14 \mathrm{~d})$ as evidenced by their ability to grow new leaves and to withstand sun without wilting. We successfully transplanted 49 tobacco plants in 1996, 66 in 1997, 79 in 1998, 85 in 1999, and 50 in 2000. All sagebrush plants used in these experiments were already established.

Half of the transplanted tobacco plants were randomly assigned to be near a clipped sagebrush and half were assigned to be near an unclipped control sagebrush. We clipped and removed the sagebrush shoot within $15 \mathrm{~cm}$ of tobacco with scissors for plants assigned to this treatment on 7 July 1996, 25 June 1997, 1 July 1998, 23 June 1999, or 23 June 2000. Different sagebrush plants were used in each of the five years. For each tobacco plant, we recorded the number of perfect flowers produced throughout the growing season, a likely correlate of male fitness, and the number of filled capsules that contained seeds, a likely correlate of female fitness. We also attempted to collect all the
TABLE 1. Analysis of variance of the production of flowers and filled capsules for tobacco plants with clipped or unclipped sagebrush neighbors for 1996-2000 on the floodplain of Convict Creek at the Sierra Nevada Aquatic Research Laboratory (SNARL) near Mammoth Lakes, California, USA.

\begin{tabular}{lrrrrc}
\hline \multicolumn{1}{c}{ Source } & ss $\dagger$ & df & MS & $F$ & $P$ \\
\hline A) Flowers & & & & & \\
Clipping & 266 & 1 & 266 & 10.87 & 0.001 \\
Year X Clipping & 289 & 4 & 72 & 2.95 & 0.020 \\
Year & 120 & 4 & 30 & 1.22 & 0.301 \\
Error & 7038 & 288 & 24 & & \\
B) Filled capsules & & & & & \\
Clipping & 49 & 1 & 49 & 7.11 & 0.008 \\
Year X Clipping & 71 & 4 & 18 & 2.61 & 0.036 \\
Year & 143 & 4 & 36 & 5.24 & 0.001 \\
Error & 1966 & 288 & 7 & & \\
\hline
\end{tabular}

$\dagger$ Type III sums of squares are reported in all analyses.

seeds contained within those capsules. This was not a reliable estimate since seeds began falling from capsules as soon as they matured, and we were unable to collect seeds frequently enough to capture all of them. Grasshoppers feed on leaves, flowers, and capsules. Plants filled only about half of their flowers. We do not know if herbivory on reproductive organs directly affected male fitness or the number of filled capsules. Numbers of flowers and capsules produced by each plant were analyzed in two separate ANOVAs with treatment (clipped or unclipped sagebrush neighbors), year, and year $\times$ treatment interaction as effects.

We also evaluated levels of herbivore damage on tobacco leaves with clipped and unclipped sagebrush neighbors. We monitored the proportion of wild tobacco leaves that were naturally damaged by herbivores every fifth day throughout the entire season. The maximum proportion of leaves with damage by herbivores was used as a nondestructive measure of damage for each plant and was arcsine square-root transformed for analyses. A destructive sample of other plants that were not used in these experiments indicated that this measure of herbivory was correlated with the percentage of leaf area removed $\left(R^{2}=0.46, n=50, P<0.001\right)$. Tobacco plants used to determine reproductive performance were the same ones evaluated for damage by herbivores.

\section{RESUlts}

Plant performance was evaluated during five seasons by considering two related measures, number of flowers and number of filled capsules produced per plant. Many flowers never produced mature capsules but did produce pollen. Therefore, flower number reflected potential male fitness but was not the best estimate of potential female fitness. Clipping neighboring sagebrush affected production of both flowers and capsules but the effect varied from year to year (significant year $\times$ clipping interaction in Table 1A, B). Tobacco plants with clipped sagebrush neighbors produced many more 

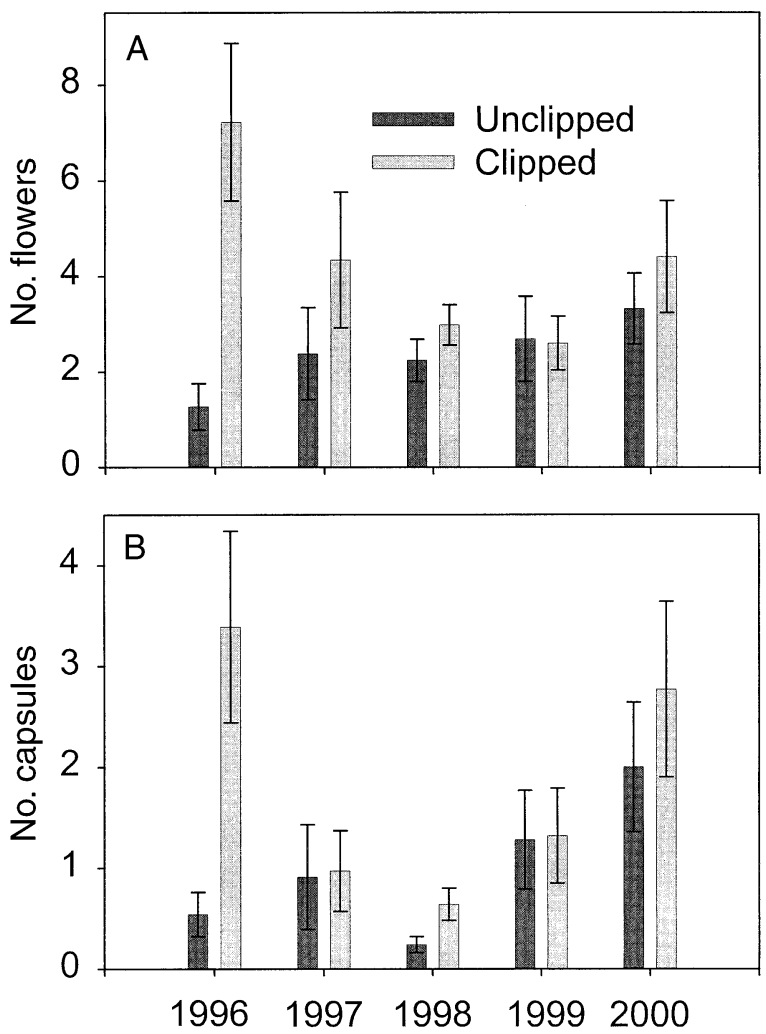

FIG. 1. (A) Number of flowers produced per tobacco plant with clipped or unclipped sagebrush neighbors from 1996 to 2000 on the floodplain of Convict Creek at the Sierra Nevada Aquatic Research Laboratory (SNARL) near Mammoth Lakes, California, USA (means $\pm 1 \mathrm{SE}$ ). (B) Number of capsules containing filled seeds per tobacco plant with clipped or unclipped sagebrush neighbors (means $\pm 1 \mathrm{SE}$ ).

flowers than those with unclipped neighbors in 1996, produced a few more flowers in 1997, 1998, and 2000 and produced no more in 1999 (Fig. 1A). Tobacco plants with clipped neighbors produced more filled capsules than those with unclipped neighbors in 1996 and 1998 but no more in 1997, 1999, and 2000 (Fig. 1B). In no year did tobacco plants with unclipped neighbors outproduce those with clipped neighbors. Production

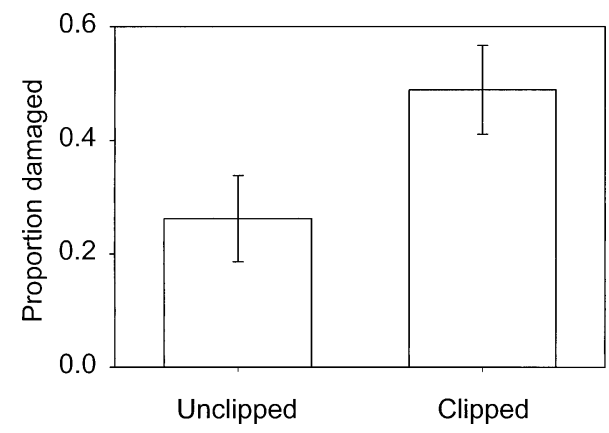

FIG. 2. Proportion of leaves of tobacco plants that were damaged by frost with clipped or unclipped sagebrush neighbors (means $\pm 1 \mathrm{SE}$ ).
TABLE 2. The maximum proportion of leaves that were damaged by naturally occurring grasshoppers during each season for tobacco plants near (within $15 \mathrm{~cm}$ ) clipped or unclipped sagebrush neighbors (means $\pm 1 \mathrm{SE}$ ).

\begin{tabular}{lccc}
\hline \hline & \multirow{2}{*}{$\begin{array}{c}\text { Sample } \\
\text { Year }\end{array}$} & \multicolumn{2}{c}{ Proportion damaged leaves } \\
\cline { 3 - 4 } & size & Near unclipped & Near clipped \\
\hline 1996 & 49 & $0.58 \pm 0.07$ & $0.30 \pm 0.06$ \\
1997 & 66 & $0.79 \pm 0.04$ & $0.64 \pm 0.06$ \\
1998 & 79 & $0.57 \pm 0.05$ & $0.47 \pm 0.04$ \\
1999 & 85 & $0.72 \pm 0.05$ & $0.54 \pm 0.04 \ddagger$ \\
2000 & 50 & $0.60 \pm 0.05$ & $0.48 \pm 0.08$ \\
\hline
\end{tabular}

$\dagger$ Approximately half of the plants were assigned to each of the two treatments.

$\ddagger$ Includes plants clipped both by scissors and herbivores.

of flowers and capsules was strongly negatively correlated with maximum levels of damage to leaves (data not shown).

On the morning of 1 July 1997, the study site experienced a hard freeze that killed some tobacco leaves and individuals in the study. Leaves and stems killed by frost became uniformly brown and lost all turgor. The proportion of leaves killed on plants of the two treatments was recorded, transformed, and analyzed by ANOVA. Tobacco plants close to clipped sagebrush suffered $87 \%$ higher frequency of leaf damage by frost compared to tobacco close to unclipped sagebrush (Fig. $\left.2 ; F_{1,59}=4.24, P=0.044\right)$. Frost damage to leaves was reflected in plant mortality; 11 of 32 plants (34\%) close to clipped sagebrush died because of frost damage compared to 6 of 29 plants $(21 \%)$ close to unclipped sagebrush. This difference in plant mortality was not statistically significant with the limited sample size $\left(\chi^{2}\right.$ $=1.42$, df $=1, P>0.20)$.

Herbivore densities and the damage they caused varied considerably from year to year (Table 2; year was significant in Table 3). However, over all five years, tobacco plants near clipped sagebrush received less damage to their leaves than plants near unclipped sagebrush (clipping was significant in Table 3 ). This effect was consistent from year to year (year $\times$ clipping was not significant; Table 3).

\section{DISCUSSION}

Tobacco near clipped sagebrush suffered reduced levels of maximum leaf loss by herbivores (Tables 2 and 3). These results were consistent over five years

TABLE 3. Analysis of variance of the maximum proportion of tobacco leaves that were damaged by grasshoppers during each season near clipped or unclipped sagebrush neighbors.

\begin{tabular}{lrrrrc}
\hline \hline \multicolumn{1}{c}{ Source } & \multicolumn{1}{c}{ ss } & \multicolumn{1}{c}{ df } & \multicolumn{1}{c}{ MS } & \multicolumn{1}{c}{$F$} & $P$ \\
\hline Clipping & 10886 & 1 & 10886 & 18.85 & 0.001 \\
Year × Clipping & 2255 & 4 & 564 & 0.98 & 0.421 \\
Year & 19963 & 4 & 4991 & 8.64 & 0.001 \\
Error & 163420 & 283 & 577 & & \\
\hline
\end{tabular}


and extend those reported by Karban et al. (2000). However, no previous work in this or any other system has indicated whether plants that induce resistance as a result of cues released by neighbors will experience measurable fitness consequences.

Herbivory has been shown to affect plant reproduction in this system. Leaf damage to a related tobacco species reduced lifetime seed production in the laboratory (Ohnmeiss and Baldwin 2000). N. attenuata in natural populations that were experimentally induced with a chemical elicitor, methyl jasmonate, suffered less damage from herbivores and realized higher lifetime seed production than untreated plants under some conditions (Baldwin 1998).

In the study reported here, induction caused by clipping sagebrush reduced herbivory on neighboring tobacco and led to increased flowering and capsule production of these plants in some years but not in others (Fig. 1A, B). In years when clipping neighbors did not increase tobacco flowers and capsules, there was no indication that growing near a clipped neighbor reduced tobacco fitness relative to plants growing near unclipped neighbors. In other words, we never observed a net cost of inducing resistance for tobacco plants growing near clipped sagebrush.

An unexpected fitness cost associated with having clipped neighbors was greater risk of frost damage (Fig. 2). Frost was not uncommon at this study site during the seven growing seasons from 1994 to 2000. During this time, a hard frost occurred in 1997 that caused leaf loss and even plant death, and a milder frost occurred in 1999 that did not cause symptoms at the study site but did damage tobacco plants at similar elevations several kilometers away. The increased risk of frost damage for plants with clipped sagebrush neighbors may have been associated with a cost of induction or with an altered microenvironment. However, an altered microenvironment was not responsible for the reduced herbivore damage to tobacco with clipped sagebrush neighbors (Karban et al. 2000). It is important to note that even in 1997 when tobacco with clipped neighbors suffered greater frost damage, net seed production near clipped sagebrush was no lower than that near unclipped sagebrush neighbors (Fig. 1B). Although the five years were different, when considered together, growing near clipped sagebrush rather than unclipped sagebrush improved reproductive performance for tobacco plants.

Theory predicts that plants will respond to information released by damaged neighbors only if the information is reliable and allows them to respond appropriately to increase fitness (Levins 1968, Lloyd 1984, Lively 1986, 1999, Adler and Karban 1994, Getty 1996 , Jaremo et al. 1999, Karban et al. 1999). In years when densities of herbivores were high, the information that tobacco plants received from experimentally clipped sagebrush neighbors was probably an accurate reflection of increased risk to tobacco. As such, increased tobacco fitness was only expected in years with high herbivory. In years when densities of herbivores were low, tobacco received "misinformation" from experimentally clipped sagebrush about the risk of herbivory. Under those conditions, responding to cues to increase resistance is expected to decrease tobacco fitness. This line of reasoning predicts that the reproductive advantage for tobacco near clipped neighbors should have been greatest in the years when herbivory was highest (1997 and 1999).

This prediction was not upheld for capsule production. To the contrary, the years of greatest herbivore risk (1997 and 1999) were the years when growing near clipped sagebrush was least beneficial to tobacco plants (Fig. 1B). This counterintuitive pattern was the same one found when wild tobacco plants were experimentally induced with methyl jasmonate (Baldwin 1998). For plants with no herbivores in that study, artificially induced resistance reduced capsule production. For plants with a low risk of herbivory, induction reduced leaf damage and increased capsule production. However, induction did not increase fitness of plants suffering high risks of herbivory.

There are many possible explanations for the apparent lack of fine tuning between the risk of herbivory and the strength of the fitness advantage resulting from eavesdropping. The theory that has been developed assumes a highly adapted response by tobacco plants to cues released by sagebrush naturally damaged by generalist herbivores.

The response we observed may derive from the fact that tobacco, like most plants, uses a jasmonate signaling system (Staswick 1992, Reinbothe et al. 1994, Baldwin 1996, Karban and Baldwin 1997), and damaged sagebrush releases large amounts of methyl jasmonate (Farmer and Ryan 1990, Karban et al. 2000). Initially, selection may have favored plants that used methyl jasmonate signaling to regulate their own internal defenses and other traits as well (Creelman and Mullet 1995, Karban and Baldwin 1997). Indeed, jasmonates have been shown to play a role in both flower production and plant senescence. This may predispose plants to respond by flowering or becoming sensitive to frost after receiving a strong jasmonate signal released by damaged sagebrush. This scenario does not predict a close correspondence between risk of herbivory and benefits for plants that respond to cues released by neighbors.

This latter explanation suggests that many other plants that use jasmonate signaling and grow in association with sagebrush might also induce resistance when neighboring sagebrush is clipped. These induced responses may or may not increase the expected fitness of the plants that respond. Any adaptive benefits of eavesdropping remain unclear although we are planning to examine this question in the future.

In replicated experiments over five seasons involving randomly assigned clipping treatments, we found that 
tobacco near clipped sagebrush neighbors became more resistant to herbivory compared to tobacco near unclipped neighbors. Resistance in tobacco induced by eavesdropping never decreased measures of lifetime plant fitness and actually increased flower and capsule production in some years. Whether this phenomenon is unique to tobacco or is more widespread is unknown. However, the simple fact that plants have been shown to eavesdrop on cues emitted by other plants in the field indicates that the spectrum of interactions within communities may be even richer than we now appreciate.

\section{ACKNOWLEDGMENTS}

We thank Kim Baxter, Max Korten, Laura Richards, Anurag Agrawal, and Claire and Jesse Karban for help with fieldwork. We benefited from conversations or criticisms provided by Lynn Adler, Anurag Agrawal, Gary Ervin, Gary Felton, Andy McCall, Erik Nelson, Mike Stout, Sharon Strauss, Nora Underwood, Robin Waugaman, and Truman Young. Much of this work was conducted at the UC Sierra Nevada Aquatic Research Laboratory and Dan Dawson was a helpful and resourceful facilitator. We were supported by USDA NRI 9602065, 9802362 and NSF DEB 0121050.

\section{Literature Cited}

Adler, F. R., and R. Karban. 1994. Defended fortresses or moving targets? Another model of inducible defenses inspired by military metaphors. American Naturalist 144: 813-832.

Baldwin, I. T. 1996. Methyl jasmonate-induced nicotine production in Nicotiana attenuata: inducing defenses in the field without wounding. Entomologia experimentalis et applicata 80:213-220.

Baldwin, I. T. 1998. Jasmonate-induced responses are costly but benefit plants under attack in native populations. PNAS 95:8113-8118.

Baldwin, I. T., and J. C. Schultz. 1983. Rapid changes in tree leaf chemistry induced by damage: evidence for communication between plants. Science 221:277-279.

Bradbury, J. W., and S. L. Vehrencamp. 1998. Principles of animal communication. Sinauer, Sunderland, Massachusetts, USA.

Bruin, J., M. Dicke, and M. W. Sabelis. 1992. Plants are better protected against spider-mites after exposure to volatiles from infested conspecifics. Experientia 48:525-529.

Bruin, J., M. W. Sabelis, and M. Dicke. 1995. Do plants tap SOS signals from their infested neighbors? Trends in Ecology and Evolution 10:167-170.

Creelman, R. A., and J. E. Mullet. 1995. Jasmonic acid distribution and action in plants: Regulation during development and response to biotic and abiotic stress. PNAS 92: 4114-4119.

Farmer, E. E., and C. A. Ryan. 1990. Interplant communi- cation: airborne methyl jasmonate induced synthesis of proteinase inhibitors in plant leaves. PNAS 87:7713-7716.

Fowler, S. V., and J. H. Lawton. 1985. Rapidly induced defenses and talking trees: the devil's advocate position. American Naturalist 126:181-195.

Getty, T. 1996. The maintenance of phenotypic plasticity as a signal detection problem. American Naturalist 148:378385 .

Jaremo, J., J. Tuomi, and P. Nilsson. 1999. Adaptive status of localized and systemic defense responses in plants. Pages 33-44 in R. Tollrian and C. D. Harvell, editors. The ecology and evolution of inducible defenses. Princeton University Press, Princeton, New Jersey, USA.

Karban, R., A. A. Agrawal, J. S. Thaler, and L. S. Adler. 1999. Induced plant responses and information content about risk of herbivory. Trends in Ecology and Evolution 14:443-447.

Karban, R., and I. T. Baldwin. 1997. Induced responses to herbivory. University of Chicago Press, Chicago, Illinois, USA.

Karban, R., I. T. Baldwin, K. J. Baxter, G. Laue, and G. W. Felton. 2000. Communication between plants: induced resistance in wild tobacco plants following clipping of neighboring sagebrush. Oecologia 125:66-71.

Karban, R., and K. J. Baxter. 2001. Induced resistance in wild tobacco with clipped sagebrush neighbors: the role of herbivore behavior. Journal of Insect Behavior 14:147-156.

Levins, R. 1968. Evolution in changing environments. Princeton University Press, Princeton, New Jersey, USA.

Lively, C. M. 1986. Competition, comparitive life histories, and maintenance of shell dimorphism in a barnacle. Ecology 67:858-864.

Lively, C. M. 1999. Developmental strategies in spatially variable environments: barnacle shell dimorphism and strategic models of selection. Pages 245-258 in R. Tollrian and C. D. Harvell, editors. The ecology and evolution of inducible defenses. Princeton University Press, Princeton, New Jersey, USA.

Lloyd, D. G. 1984. Variation strategies of plants in heterogeneous environments. Biological Journal of the Linnean Society 21:357-385.

Ohnmeiss, T. E., and I. T. Baldwin. 2000. Optimal defense theory predicts the ontogeny of an induced nicotine defense. Ecology 81:1765-1783.

Reinbothe, S., B. Mollenhauer, and C. Reinbothe. 1994. JIPs and RIPs: the regulation of plant gene expression by jasmonates in response to environmental cues and pathogens. Plant Cell 6:1197-1209.

Rhoades, D. F. 1983. Responses of alder and willow to attack by tent caterpillars and webworms: evidence for pheromonal sensitivity of willows. Pages 55-68 in P. A. Hedin, editor. Plant resistance to insects. American Chemical Society, Washington, D.C., USA.

Shonle, I., and J. Bergelson. 1995. Interplant communication revisited. Ecology 76:2660-2663.

Staswick, P. E. 1992. Jasmonate, genes, and fragrant signals. Plant Physiology 99:804-807.

Wells, P. V. 1959. An ecological investigation of two desert tobaccos. Ecology 40:626-644. 